\title{
Renal Cell Carcinoma Manifesting After Extracorporeal Shockwave Lithotripsy, Percutaneous Nephrolithotomy and Open Surgery For Cystine Calculus
}

\author{
Sistin Taşı Nedeniyle Yapılan Vǚut Dışı Şok Dalga Tedavisi, Perkütan Nefrolitotomi ve \\ Açık Cerrahi Sonrası Görülen Renal Hücreli Karsinom \\ Mustafa KAPLAN ${ }^{1}$, Eric KLEIN ${ }^{2}$ \\ ${ }^{1}$ Trakya Üniversitesi Tip Fakïltesi, Üroloji Anabilim Dalı, Edirne \\ ${ }^{2}$ Department of Urology, Cleveland Clinic Foundation, Cleveland
}

Submitted / Başvuru tarihi: 16.09.2008 Accepted / Kabul tarihi: 04.12.2008

\begin{abstract}
Several studies have linked nephrolithiasis with an increased risk of renal pelvis cancer but an association between nephrolithiasis and risk of renal cell carcinoma (RCC) has not been apparent, as only a few cases of RCC developing with nephrolithiasis have been reported. Herein, we report a case of bilateral RCC, which developed in a patient who had bilateral renal calculus, which was previously managed by extracorporeal shock wave lithotripsy, percutaneous nephrolithotripsy, and open surgery. All patients with a long standing history of urolithiasis should undergo close scrutiny of the parenchyma for the possibility an occult renal cancer by using appropriate investigations.

Key words: Calculus; cystine; renal cell carcinoma.
\end{abstract}

Böbrek taş hastalığının renal pelvis kanseri için önemli bir risk faktörü olduğu yönünde bir çok araştırma olsa da böbrek taş hastalığı ile renal hücreli karsinom birlikteliği çok iyi bilinmemekte ve bu konuda çok az olgu sunumu tarzında yayın mevcuttur. Biz burada bilateral böbrek taşı nedeniyle daha önce vücut dışı şok dalgaları, perkütan nefrolitotripsi ve açık cerrahi sonrası bilateral renal hücreli karsinom tanısı alan bir olguyu sunmaya çalıştık. Uzun süreli böbrek taşı bulunan olguların uygun yöntemlerle renal parankim tümörü açısından da izlenmesi gerekir.

Anahtar sözcükler: Renal hücreli karsinom; sistin; taş.
Several studies have linked nephrolithiasis with an increased risk of renal pelvis cancer ${ }^{[1-5]}$ but an association between nephrolithiasis and risk of renal cell carcinoma (RCC) has not been apparent, as only a few cases of RCC developing with nephrolithiasis have been reported. ${ }^{[6-10]}$ The role of renal calculi in the genesis of RCC is not well known. Herein, we report a case of bilateral RCC which developed in a patient who had bilateral renal calculus, which was previously managed by extracorporeal shock wave lithotripsy (ESWL), percutaneous nephrolithotripsy (PCNL), and open surgery.

\section{CASE REPORT}

A 47-year-old white female presented with right upper quadrant pain. She had a history of cystine stones and multiple bilateral renal calculi. She had had multiple shock wave lithotripsies to both kidneys, also 3 percutaneous nephrolithotripsy on the right kidney as well as open pyelolithotomy of her right kidney and left ureterolithotomy.

Renal ultrasound showed a right lower pole complex cyst sized 9.9x7.5 cm. Subsequent computed tomography scan was carried out and showed exophytic right renal carcinoma and exophytic left lower pole renal neoplasm. The right renal mass measured $8.8 \times 7.3 \mathrm{~cm}$ and involved the renal sinus (Figure 1). There were bilateral diffuse punctate calcifications within the renal parenchyma. The inferior pole left renal mass measured $1.8 \times 1.2 \mathrm{~cm}$. There was no evidence of extrarenal spread or lymph node 
Renal Cell Carcinoma Manifesting After Extracorporeal Shockwave Lithotripsy,

Percutaneous Nephrolithotomy and Open Surgery For Cystine Calculus

involvement (Figure 2). Because the patient had had open surgery bilaterally and multiple percutaneous procedures on the right kidney and had a small left kidney, we performed a right open partial nephrectomy. During the operation, the mass was excised while maintaining $60 \%$ of the normal renal parenchyma. Frozen section was consistent with RCC and negative margins. Final pathological evaluation of the surgical specimen revealed a clear cell type of RCC, Furhman nuclear 3 of 4 (7.8 in greatest dimension). Left kidney tumor was ultimately treated by cryotherapy.

\section{DISCUSSION}

Kidney stones are an increased risk for developing renal pelvis cancer. ${ }^{[1-5]}$ Although adenocarcinoma of renal pelvis associated with nephrolithiasis has been recorded in a few case reports, ${ }^{[3,5]}$ squamous cell carcinoma of renal pelvis is the most common renal malignancy associated with nephrolithiasis. ${ }^{[2,4,11,12]}$ It is unclear why

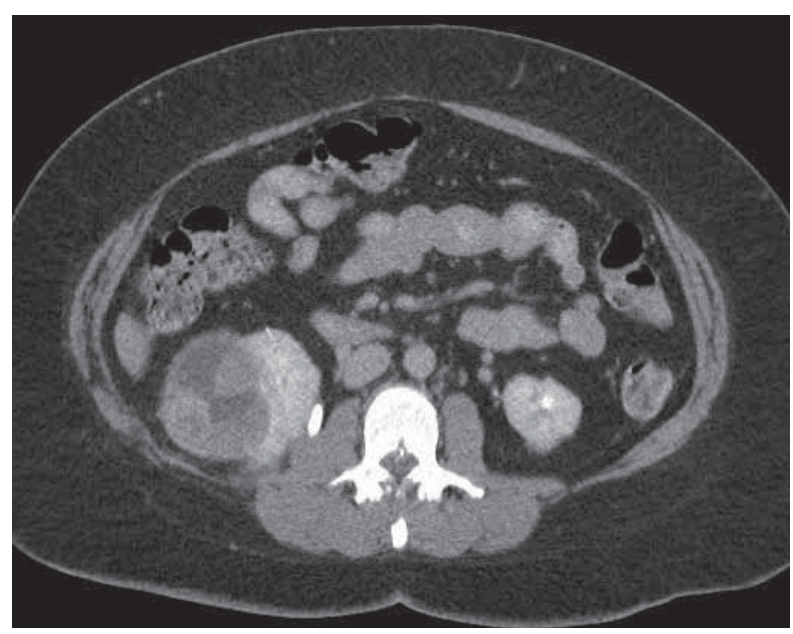

Figure 1. CT showing a large right renal mass.

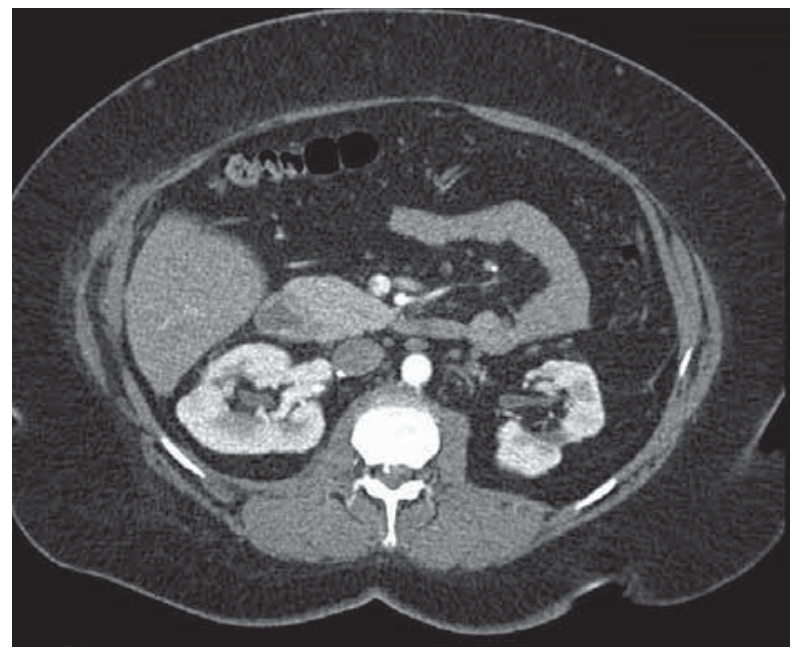

Figure 2. CT after the right partial nephrectomy showing the $2 \mathrm{~cm}$ left renal mass that was ultimately treated by cryotherapy. stones predispose to urinary tract cancer. It is generally believed that the transitional cell epithelium undergoes metaplasia caused by the presence of infection and chronic irritation by renal stones. The subsequent squamous metaplasia then becomes malignant after several years. ${ }^{[1]}$ Although the relationship between renal calculi and RCC has not been well documented, a possible association may exist between the RCC and nephrolithiasis.

Incidental detection of RCC in association with renal stone disease has been reported by some authors. ${ }^{[8-10,13,14]}$ In all reported cases, RCC was identified either at the time of renal surgery to remove the calculus ${ }^{[9]}$ or just prior to treatment..$^{[8,13,14]}$ The authors changed the operation procedure after the definite diagnosis of renal mass. Subsequently, all cases underwent radical nephrectomy instead of NSS. The authors suggested that, in patients over 50 years of age treated with PCNL or x-ray guided ESWL, ultrasound before treatment should be performed to exclude incidental renal cancer. Hes et al. ${ }^{[6]}$ found an association with nephrolithiasis in 3 out of 11 of spindle and cuboidal RCC. They presented the largest series of an unclassified subtype of RCC. In this series the most interesting clinical finding was the association with nephrolithiasis in 3 out of 11 patients. Chen et al. ${ }^{[15]}$ reported a very rare primary renal tumor, a malignant fibrous histiocytoma of kidney associated with staghorn calculi. Talamini et al. ${ }^{[16]}$ performed a hospital-based case-control study of risk factors for RCC and they found a positive association between a history of nephrolithiasis and RCC. However, in a study of patients hospitalized for kidney stones, Chow et al. ${ }^{[1]}$ found an elevated risk for causes of the renal pelvis, but they did not find an excess risk of renal cell carcinoma. In this study, a population-based cohort of patients hospitalized for kidney or ureter stones was followed for up to 25 years to examine subsequent risks for developing renal cell, pelvis/ureter, or bladder cancer.

We could not find any reported data of the occurrence of RCC several years after the treatment of calculi. Our case is the first report of RCC manifesting several years after the management of stone disease.

Although radical nephrectomy is the gold standard curative operation for patients with localized RCC, nephron sparing surgery (NSS) is now an established approach when there is a clinically relevant need to preserve renal function. Patients with synchronous renal tumors have an absolute indication for NSS, and an attempt should be made to preserve as much functioning parenchyma as possible. ${ }^{[11]}$

In conclusion, all patients with a longstanding history of urolithiasis should undergo close scrutiny of the parenchyma for the possibility of an occult renal cancer by using appropriate investigations. RCC could exist either simultaneously with stone disease or develop several years after treatment for stone disease. In a patient with 
bilateral synchronous RCC, NSS should be attempted to preserve as much functional renal tissue as possible. For the patients who had previous surgery, the open approach should be the choice since the scarring and adhesions are handled better through this technique. Early diagnosis of disease is most important for survival.

\section{Conflict of Interest}

No conflict of interest declared by the authors.

\section{REFERENCES}

1. Chow WH, Lindblad P, Gridley G, Nyrén O, McLaughlin JK, Linet MS, et al. Risk of urinary tract cancers following kidney or ureter stones. J Natl Cancer Inst 89 1997;1453-7.

2. Li MK and Cheung WL. Squamous cell carcinoma of the renal pelvis. J Urol 1987;138:269-71.

3. Kaur G, Naik VR, Rahman MN. Mucinous adenocarcinoma of the renal pelvis associated with lithiasis and chronic gout. Singapore Med J 2004;45:125-6.

4. Sivaramakrishna B, Aron M, Ansari MS, Seth A, Goel R, Mundada OP, et al. Squamous cell carcinoma of the renal pelvis manifesting after percutaneous nephrolithotomy for long standing calculus. Int Urol Nephrol 2004;36:149-51.

5. Tsuzuki T, Kouketsu H, Ono K, Kobayashi H, Obata K. Primary adenocarcinoma of the renal pelvis with special reference to histochemical observations. Pathol Int 1996;46:791-6.

6. Hes O, Hora M, Perez-Montiel DM, Suster S, Curík R, Sokol $\mathrm{L}$, et al. Spindle and cuboidal renal cell carcinoma, a tumor having frequent association with nephrolithiasis: report of 11 cases including a case with hybrid conventional renal cell carcinoma/spindle and cuboidal renal cell carcinoma components. Histopathology 2002;41:549-55.
7. Cowley JP, Connolly CE, Hehir M, O’Beirn SF. Renal carcinoma with staghorn calculus, perinephric abscess, and xanthogranulomatous pyelonephritis in same kidney. Subcutaneous abscess of thigh as initial presentation. Urology 1983;21:635-8.

8. Devarajan R, Cox P, Arkell DG, Kadow C, Hughes MA, Sole $\mathrm{GM}$, et al. Incidental renal cell carcinoma with renal calculus disease: a series of five cases. BJU Int 1999;84:1104-6.

9. Oesterling JE, Kerr LA, Segura JW. Branched, struvite calculus and clear cell carcinoma in same kidney. Rare condition with significant implications for management. Urology 361990;273-6.

10. Indudhara R, Goswami AK, Choudhary SR, Sarode VR. Coexisting renal cell carcinoma and xanthogranulomatous pyelonephritis in a chronic calculous disease. Urol Int 1992;48:450-2.

11. Novick AC, Derweesh I. Open partial nephrectomy for renal tumors: current status. BJU Int 2005;95:35-40.

12. Reed HM, Robinson ND. Horseshoe kidney with simultaneous occurrence of calculi, transitional cell and squamous cell carcinoma. Urology 1984;23:62-4.

13. Ansari MS, Singh I, Gupta NP. Renal stone masquerading as an occult renal cell cancer (incidental RCC). Int Urol Nephrol 2004;36:235-7.

14. Parr NJ, Ritchie AW, Moussa SA, Tolley DA. Incidental renal carcinoma discovered during ultrasound localization of renal calculi for extracorporeal piezoelectric lithotripsy. BJU 1991;68:211-2.

15. Chen $\mathrm{CH}$, Lee PS, Han WJ, Shen KH. Primary giant cell malignant fibrous histiocytoma of the kidney with staghorn calculi. J Postgrad M 2003;49:246-8.

16. Talamini R, Barón AE, Barra S, Bidoli E, La Vecchia C, Negri $\mathrm{E}$, et al. A case-control study of risk factor for renal cell cancer in northern Italy. Cancer Causes Control 1990;1:125-31. 